УДК 347.91:342.5

DOI https://doi.org/10.32837/yuv.v0i2.2146

\author{
В. Коротун, \\ кандидат юридичних наук, \\ суддя \\ Касаційного цивільного суду у складі Верховного Суду
}

\title{
ВИРІШЕННЯ ПРАВОВИХ СПОРІВ ІЗ ПІДСТАВ ПОРУШЕННЯ ПРАВИЛ ПРЕДМЕТНОЇ ЧИ СУБ'ЄКТНОЇ ЮРИСДИКЦІї
}

Вступ. Проблема розмежування судової юрисдикції виникає у будьякій сучасній демократичній державі, якщо судоустрій у такій державі будується за принципами територіальності та спеціалізації. Інакше кажучи, якщо в державі функціонують, щонайменше, дві відносно автономні підсистеми судів. Для розв'язання спорів про визначення судової юрисдикції нині не сформовано єдиного або універсального підходу для вирішення цієї проблеми, принаймні в європейських державах. Необхідно визнати, що до оновлення в 2017 р. судоустрою і галузевих процесуальних кодексів проблемою розмежування судової юрисдикції опікувались на паритетних умовах вищі спеціалізовані суди, Верховний Суд України. Проте ефективність такої роботи не відповідала вимогам, які сформульовані в галузевих процесуальних кодекcax як завдання та основні засади судочинства. Між тим правозастосовна діяльність Великої Палити Верховного Суду під час розгляду справ з підстав порушення правил предметної чи суб'єктної юрисдикції ускладнюється внаслідок багатьох факторів.

Метою статті $€$ порівняльний аналіз окремих аспектів нормативного регулювання функціонування судових інституцій в Україні і Франції, які опікуються розв'язанням правових спорів про судову юрисдикцію, та формулювання відповідних авторських висновків та пропозицій.
Виклад основного матеріалу. Перш ніж перейти до аналізу окремих аспектів нормативного регулювання діяльності судових інституцій в Україні і Франції, які вирішують спори про судову юрисдикцію, важливо розглянути окремі аспекти різного визначення поняття підвідомчості, юрисдикції, що тривалий час розглядалися у наукових вітчизняних часописах, та причини, що спонукали законодавця використовувати поняття «юрисдикція» в ЦПК, ГПК України. На нашу думку, важливість такого підходу полягає в глибокому та всебічному дослідженні цього правового явища вченими-процесуалістами радянської школи та вченими України в новітні часи. Необхідно також стисло визначитись з обгрунтуванням використання автором іншої назви суду, ніж у перекладі видання Цивільного процесуального кодексу Франції та додатків 1-4 [1], оскільки на це видання автор у порівняльному аналізі буде посилатись.

Назва суду Франції в перекладі вказана як Суд у спорах про підсудність справ (Tribunal des conflits) [1, с. 941]. Не ставлячи під сумнів фаховість перекладу Процесуального кодексу Франції, було б помилковим розглядати функцію Tribunal des conflits крізь призму перекладу назви цього суду. На нашу думку, поняття «підсудність» розмежовує компетенцію вже непросто державних органів, а виокремлює компетенцію судів 
3 розгляду справ. Необхідно зазначити, що у вітчизняній науковій літературі назву Tribunal des conflits ще в 2015 р. перекладали як Суд зі спорів про юрисдикцію [2], а тому і автор буде використовувати такий варіант перекладу тлумачення назви суду Франції.

Не ототожнюючи юрисдикцію та підвідомчість, усе ж не можна не помітити певною мірою використання вченими у дослідженні цих питань однакових за змістом та сутністю категорій.

Поняття підвідомчості, як правило, не викликає жодних питань у науковій юридичній літературі, окрім, можливо, деяких визначень мовних категорій, наукових понять, ї ототожнення тощо. Свого часу М.Й. Штефан розглядав підвідомчість крізь призму розмежування компетенції органів держави, а компетенцію суду в здійсненні правосуддя як розгляд і вирішення визначеної певної категорії питань або підвідомчість судових органів. Зазначається, що підвідомчість необхідно розрізняти крізь призму того чи іншого юрисдикційного органу, оскільки право вирішення цивільних справ за законодавством України надано не тільки судовим, але й іншим органам держави, громадським організаціям, змішаним органам, третейським судам. Указаний автор ототожнював категорії «судова юрисдикція» та «підвідомчість судових органів» [3, с. 171]. Енциклопедичні джерела також розглядають підвідомчість як розмежування компетенції органів держави та недержавних суб'єктів [4, с. 535].

Інша група авторів дещо інакше розглядає співвідношення категорій «цивільна юрисдикція» та «підвідомчість цивільних справ». Звісно, це категорії різного рівня узагальнення правових явищ, але в обох випадках дослідники аналізують одні й ті самі правові питання. Зокрема, С.С. Бичкова вказує, що поняття «цивільна юрисдикція» означає компетенцію відповідних юрисдикційних органів з розгляду цивільних справ, а властивість цивільних справ, за допомогою якої їх розгляд і вирішення віднесено законом до компетенції відповідного юрисдикційного органу, є підвідомчістю цивільних справ [5, с. 93]. Видається, що у вищенаведеному випадку спроба розмежувати категорії «цивільна юрисдикція» i «підвідомчість цивільних справ» невдала, на нашу думку, оскільки не вказано формалізований критерій такого розмежування.

Свого часу один з авторів, розмірковуючи про закріплену в Конституціï України доктрину необмеженості юрисдикції судів, справедливо дійшов висновку, що інститут підвідомчості за своєю сутнісною природою не відповідає Конституції України, оскільки вона закріпила необмежену юрисдикцію судів, а конструкція підвідомчості грунтувалася на засадах поділу юрисдикціі, тобто коли справи розглядалися багатьма юрисдикційними органами, а не лише тільки судом [6, с. 47]. Справді, у минулому за ЦПК України 1963 р. [7] розмежування повноважень між судами та іншими органами щодо захисту цивільних справ було регламентоване нормами інституту судової підвідомчості крізь призму перелічених правовідносин, певного суб'єкта, за винятком випадків, коли вирішення таких спорів відносилось законом до відання інших органів. Однак питання судової підвідомчості не зникло у зв'язку із закріпленням у Конституції вказаної доктрини, хоча б тому, що нормативно у законодавстві України функціонує визначена підвідомчість справ юрисдикційних органів.

3 цього питання у науковій літературі висловлені міркування про обмеженість визначення поняття судової юрисдикції, у тому числі і цивільної юрисдикції. Зазначається, що «в процесуальному законодавстві не міститься легального визначення судової юрисдикції... в деяких нормативних актах вона ототожнюється 3 підвідомчістю (ст. 12 ГПК, ст. 6 Закону України від 11 травня 2004 р. 
«Про третейські суди»)» [8, с. 246]. Видається, що такий висновок не зовсім співвідноситься 3 нормами ЦПК України. Справді, норми ЦПК України не використовують категорію «підвідомчість цивільних справ», проте визначення у ЦПК України цивільної юрисдикції як певної компетенції судів щодо захисту порушених, невизнаних або оспорюваних прав, свобод чи інтересів, що виникають із цивільних, житлових, земельних, сімейних, трудових відносин (ч. 1 ст. 19 ЦПК України) [9], дає підстави зробити висновок про правомірність ототожнення понять «цивільна юрисдикція» та «підвідомчість цивільних справ».

У правозастосовній діяльності судів останніми роками сформувався здебільшого однаковий підхід до визначення юрисдикції за предметом, суб'єктом і прямою вказівкою у законі. Водночас не можна не погодитись $з$ колегою, що проблема розмежування предметної та суб'єктної юрисдикції на практиці виникає дуже часто, тому що врегулювати питання розмежування судової юрисдикції на законодавчому рівні, визначивши чіткі критерії процедури, неможливо [10]. Отже, проблема розмежування судової юрисдикції існує та іiі подолання шляхом покращення законодавства фактично неможливе, якщо не повернутись у старе минуле, коли функціонувала єдина система загальних судів. У цьому контексті виникає питання: чи оптимально унормовані процедури розгляду правових спорів про судову юрисдикцію? Водночас слушним також $є$ питання про те, яким чином вирішуються аналогічні правові суперечки в державах $€ C$, наприклад, у тій же самій Франціï, процесуальне законодавство якої багатьма науковцями розглядається як взірець, як приклад для запозичення нормативного регулювання.

Необхідно визнати, що помилки в правозастосовній діяльності щодо визначення юрисдикції суттєво гальмують і ускладнюють касаційне провадження в Україні. Так, порушення правил юрисдикції загальних судів, визначених статтями 19-22 ЦПК України, є обов'язковою підставою для скасування рішення незалежно від доводів касаційної скарги (ч. 2 ст. 414 ЦПК України). Окрім цього, законодавець визначив окрему процедуру розв'язання правових спорів у Верховному Суді про порушення правил предметної чи суб'єктної юрисдикції.

Відповідно до ч. 6 ст. 403 ЦПК України справа підлягає передачі на розгляд Великої Палати Верховного Суду, коли учасник справи оскаржує судове рішення з підстав порушення правил предметної чи суб'єктної юрисдикції, крім випадків, вказаних у ЦПК України.

Необхідно зазначити, що справа, передана на розгляд Великої Палати Верховного Суду, коли учасник справи оскаржує судове рішення з підстав порушення правил предметної чи суб’єктної юрисдикції, не розглядається по суті заявлених у суді першої інстанції вимог. У кращому випадку в разі закриття судом касаційної інстанції провадження у справі на підставі пункту 1 ч. 1 ст. 255 ЦПК України (справа не підлягає розгляду в порядку цивільного судочинства) суд за заявою позивача постановляє в порядку письмового провадження ухвалу про передачу справи для продовження розгляду до суду першої інстанції, до юрисдикції якого віднесено розгляд такої справи, крім випадків закриття провадження щодо кількох вимог, які підлягають розгляду в порядку різного судочинства, чи передачі справи частково на новий розгляд або для продовження розгляду. У разі наявності підстав для підсудності справи за вибором позивача у його заяві має бути зазначено лише один суд, до підсудності якого належить вирішення спору.

У Франції вирішення проблеми розмежування судової юрисдикції має давні традиціï. Tribunal des conflits - 
спеціальний паритетний суд, заснований у 1872 р., для розгляду спорів про судову юрисдикцію між судами загальної юрисдикції та судами адміністративної юрисдикції. На думку дослідників, в ієрархії судів цей суд посідає друге місце після Конституційної Ради [2, с. 941].

Вказаний суд складається з восьми суддів та його очолює Міністр юстиціï. Трьох суддів вибирають члени Державної ради зі свого складу (суд, що очолюе систему адміністративних судів - виділено автором В.К.), трьох суддів вибирає зі свого складу Касаційний суд загальної юрисдикції та двох членів вибирають більшістю голосів указані шість суддів. Судді вибираються на три роки і можуть бути переобрані без обмежень у кількості виборів. Для ухвалення належного рішення кворум становить п'ять членів суду. Рішення у справі приймається лише після розгляду письмової доповіді, складеної одним із суддів, i висновку органів прокуратури, функції якої виконують дві особи, що призначаються для цієї мети Президентом Республіки щороку з членів Державної ради і Касаційного суду. В літературі зазначається, що кількість справ, щорічно розглянутих Судом зі спорів про юрисдикцію (Tribunal des conflits), не перевищує п’ятдесяти [1, с. 941].

Справа про визначення судової юрисдикції підлягає розгляду таким судом як у разі, коли адміністративний суд і суд загальної юрисдикції претендують на судову юрисдикцію по одній й тій самій справі, так і у разі, коли суди двох різних юрисдикцій оголошують про відсутність у них відповідної юрисдикції розглядати конкретну справу.

Вказаний суд розглядає справу повторно лише у разі, коли адміністративний суд і суд загальної юрисдикції прийняли рішення, які суперечать один одному, між тими самими сторонами, щодо одного й того самого предмета спору. Скарга має бути подана заінтересованою особою протягом двох місяців від дня, коли за вказаним спором було прийняте останнє рішення, яке не підлягає оскарженню як у судах загальної юрисдикції, так і в судах адміністративної юрисдикції.

Необхідно визнати, що спори про судову юрисдикцію об’єктивно притаманні судовій системі держави, в якій функціонують поряд із системою загальних судів ще й суди спеціальної юрисдикції.

Видається, що головна відмінність вирішення спорів про судову юрисдикцію у Франції полягає в економії часу i ресурсів учасників судового процесу, судової системи держави. Так, Суд зі спорів про юрисдикцію у Франціi розглядає повторно справу (а не відсилає іiі до суду першої інстанції) лише у разі, коли адміністративний суд і суд загальної юрисдикції остаточно (рішення не підлягають оскарженню) прийняли рішення, які суперечать один одному, між тими самими сторонами, щодо одного й того самого предмета спору.

Натепер функцію спеціалізованого суду 3 розгляду спорів про судову юрисдикцію виконує Велика Палата Верховного Суду. Чи доцільно вказану категорію справ розглядати у такому складі? На нашу думку, відповідь на таке питання лежить у площині головних функцій цієї інституції, безумовно, це - формування єдиної правозастосовної практики. А чи буде ефективним способом формування єдиної правозастосовної практики передача справи для продовження розгляду до суду першої інстанції, до юрисдикції якого віднесено розгляд такої справи чи передачі справи частково на новий розгляд або для продовження розгляду? Видається, що розгляд справи повторно мав би значно кращі наслідки для формування єдиної правозастосовної практики розмежування судової юрисдикції. Звісно, що повторний розгляд неможливо запровадити в складі Великої Палати, однак це питання заслуговує більш детального обговорення. 
Інша сторона розглядуваного питання полягає у способах протидіï зловживанням процесуальними правами суб'єктів-ініціаторів касаційного провадження, які крізь призму вирішення спору про судову юрисдикцію намагаються скасувати рішення суду нижчої інстанції. Так, законодавець у первинній редакції ч. 6 ст. 403 ЦПК України безальтернативно визначив передачу справи на розгляд Великої Палати Верховного Суду у всіх випадках, коли учасник справи оскаржує судове рішення з підстав порушення правил предметної чи суб'єктної юрисдикції. У 2019 р. законодавець [11] ч. 6 ст. 403 ЦПК України доповнив випадками, колисправа непередається:

1) учасник справи, який оскаржує судове рішення, брав участь у розгляді справи у судах першої чи апеляційної інстанції і не заявляв про порушення правил предметної чи суб'єктної юрисдикціі;

2) учасник справи, який оскаржує судове рішення, не обгрунтував порушення судом правил предметної чи суб'єктної юрисдикції наявністю судових рішень Верховного Суду у складі колегії суддів (палати, об'єднаної палати) іншого касаційного суду у справі з подібною підставою та предметом позову у подібних правовідносинах;

3) Велика Палата Верховного Суду вже викладала у своїй постанові висновок щодо питання предметної чи суб'єктної юрисдикції спору у подібних правовідносинах.

Висновки. Таким чином, наведений перелік випадків, коли справа не підлягає передачі на розгляд Великої Палати Верховного Суду 3 підстав порушення правил предметної чи суб'єктної юрисдикції, засвідчує про спробу законодавця запобігти формуванню негативної практики зловживання процесуальними правами учасниками судового процесу. 3 іншого боку, це перелік спірний, оскільки учасник справи, який не заявляв, не обгрунтував порушення судом правил предметної чи суб'єктної юрисдикції, міг помилятись і така помилка не має бути на заваді вирішення правового спору про судову юрисдикцію. Звісно, автор не пропонує скасувати фільтри, про які йдеться у ч. 6 ст. 403 ЦПК України, проте проблема існує, наприклад, у разі коли Велика Палата Верховного Суду у подібних правовідносинах питання судової юрисдикції не розглядала, а учасник справи не заявляв, не обгрунтував порушення судом правил предметної чи суб'єктної юрисдикції.

Видається, що судова інституція, схожа за функцією до Суду зі спорів про юрисдикцію, була б здатна вирішити ці спірні питання судової юрисдикції після остаточного вирішення справи в Касаційному суді Верховного Суду. На нашу думку, до юрисдикції такої інституції необхідно віднести справи зі спору про судову юрисдикцію, коли суди різних юрисдикцій остаточно (рішення не підлягають оскарженню) прийняли рішення, які суперечать один одному, між тими самими сторонами, щодо одного й того самого предмета спору. Розгляд справи повторно мав би значно кращі наслідки для формування єдиної правозастосовної практики розмежування судової юрисдикції в Україні. Створення касаційними судами на паритетних умовах спеціалізованого суду зі спорів про юрисдикцію вирішило би проблему оперативного розмежування судової юрисдикції, коли суди різних юрисдикцій не вважають себе компетентними розглядати конкретну справу або коли паралельно розглядають справу між тими самими сторонами, щодо одного й того самого предмета спору. Звісно, тема розмежування судової юрисдикції не вичерпується проблемами, про які йдеться у статті, однак іiі актуальність потребує подальшого обговорення. 
У статті аналізуються витоки проблеми розмежування судової юрисдикиіi на сучасному етапі правозастосовної діяльності Верховного Суду. Обгрунтовуеться теза, шо у сучасних умовах проблема розмежування судової юрисдикції об’єктивно виникає у разі функціонування, щонайменше, двох підсистем судів певної юрисдикиіï. Робиться порівняльний аналіз окремих аспектів нормативного регулювання розгляду справ про судову юрисдикиію Великою Палатою Верховного Суду $i$ Судом зі спорів про юрисдикиію (Tribunal des conflits) y Франщіï. Зазначається, що головна відмінність вирішення спорів про судову юрисдикиію у Франиії полягає в економіі часу $i$ ресурсів учасників судового проиесу, судової системи держави. Так, Суд зі спорів про юрисдикиію у Франиії розглядає повторно справу (а не відсилає ї̈ до суду першої інстанціï) лище у разі, коли адміністративний суд $i$ суд загальної юрисдикиї остаточно (рішення не підлягають оскарженню) прийняли рішення, які суперечать один одному, між тими самими сторонами, щзодо одного й того самого предмета спору. На думку автора, у разі виникнення спору про судову юрисдикиію, коли суди різних юрисдикцій остаточно прийняли рішення, які суперечать один одному, між тими самими сторонами, щзодо одного й того самого предмета спору, розгляд cправи nо cymi cnopy мав би значно краші наслідки для формування єдиної правозастосовної практики у судах України.

Наведений у ЦПК, ГПК, КАС України перелік випадків, коли справа не підлягає передачі на розгляд Великої Палати Верховного Суду з підстав порушення правил предметної чи суб'єктної юрисдикиіï, скоріше засвідчує про спробу законодавия запобігти фор- муванню негативної практики зловживання процесуальними правами учасниками судового процесу. З іншого боку, изей перелік спірний, оскільки учасник судового процесу, який не заявляв, не облрунтував порушення судом правил предметної чи суб’єктної юрисдикцї, міг помилятись $і$ така помилка не має бути на заваді вирішення правового спору про судову юрисдикцію.

Ключові слова: юрисдикція, касаційне провадження, розмежування, предметна та суб’єктна юрисдикція.

Korotun V. Resolution of legal disputes on the grounds of violation of the rules of subject or subject jurisdiction

The article analyzes the origins of the problem of delimitation of judicial jurisdiction at the present stage of law enforcement activities of the Supreme Court. A comparative analysis of certain aspects of the legal regulation of cases on judicial jurisdiction is made by the Grand Chamber of the Supreme Court and the Court of Judicial Jurisdiction (Tribunal des conflits) in France. It is noted that the main difference in resolving disputes over judicial jurisdiction in France is to save time and resources of participants in the trial, the judicial system of the state. Thus, the Court of Judicial Jurisdiction in France reconsiders a case (rather than referring it to a court of first instance) only if the administrative court and the court of general jurisdiction have finally (decisions not subject to appeal) made conflicting decisions, between the same parties, on the same subject matter of the dispute. According to the author, in the event of a dispute over judicial jurisdiction, when courts of different jurisdictions finally (decisions not subject to appeal) made conflicting decisions between the same parties on the same subject matter, the case would have to be much 
better consequences for the formation of a unified law enforcement practice of delimitation of judicial jurisdiction in Ukraine.

The list of cases given in the $C P C$, $G P C, C A S$ of Ukraine, when the case is not subject to referral to the Grand Chamber of the Supreme Court on the grounds of violation of the rules of substantive or subjective jurisdiction, rather testifies to the legislator's attempt to prevent the negative practice of abuse of procedural rights. On the other hand, this list is controversial, as the party who did not declare, did not substantiate the court's violation of the rules of substantive or subjective jurisdiction could be wrong and such an error should not interfere with resolving a legal dispute over jurisdiction.

Key words: jurisdiction, cassation proceedings, delimitation, subject and subject jurisdiction.

\section{Література}

1. Гражданский проиессуальный кодекс Франции / Предисловие В.Н. Захватаев; пер. с франи., прилож. 1-4 В.Н. Захватаев. Киев : Aлерта, 2018. 960 c.

2. Червинська М.Є. Касація в цивільному процесі: становлення $і$ перспективи розвитку. Часопис иивільного і кримінального судочинства. № 5 (26). С. 71-75.
3. Штефан М.Й. Цивільний процуес : підручник для студентів юридичних спеціальностей вищих закладів освіти. Київ : Iн Юре, 1997. 608 c.

4. Юридична енциклопедія: в $6 \mathrm{~m}$. / Редкол.: Ю.С. Шемшученко та ін. Київ : Українська енциклопедія, 1998. T. 4 : Н-П. 2002. 720 c.

5. Бичкова С.С. Цивільний процесуальний статус осіб, які беруть участь у справах позовного провадження : монографія. Київ : Атіка, 2011. 420 с.

6. Комаров В.В. Новелізація цивільного процесуального законодавства. Вісник академії правових наук. 2003. 220 с.

7. Цивільний кодекс Української РСР: затверджено Верховною Радою УРСР 18.07.1963 р. Відомості Верховної Ради УРСР. 1963. № 30. Cm. 464.

8. Курс иивільного процесу : підруиник / В.В. Комаров, В.А. Бігун, В.В. Баранкова та ін. ; за ред. В.В. Комарова. Харків : Право, 2011.1352 с.

9. Князєв В. Про критеріі розмежування судової юрисдикиії розповів суддя вС. Закон і Бізнес. 21.04.2020. URL: https://zib. com.ua/142344.

10. Цивільний процесуальний кодекс України : Закон України від 18.03. 2004 р. № 1618-IV. Відомості Верховної Ради України. 2004. № 40-42. Ст. 492.

11. Про внесення змін до деяких законодавчих актів України щодо підстав передачі справи на розгляд Великої Палати Верховного Суду та щодо строків повернення справи: Закон України від 02.10. 2019 р. № 142-IX. Відомості Верховної Ради України. 2019. № 45. Ст. 291. 